\title{
Profile of Ophthalmological Diseases in Out-Patients of Shree Birendra Hospital
}

\author{
Ramesh Raj Bist ${ }^{1}$, Sagar Rajkarnikar ${ }^{l}$, Anu Gurung ${ }^{l}$, Ram Shrestha ${ }^{l}$, Pratik Chetry ${ }^{l}$. \\ ${ }^{1}$ Department of Ophthalmology, Shree Birendra Hospital, Chhauni.
}

\begin{abstract}
Introduction: The causes of blindness and the pattern of eye diseases differ in developing and developed countries and often in communities. A study of the pattern of ocular diseases is very important because while some eye conditions are just causes of ocular morbidity others invariably lead to blindness.

Methods: This was a retrospective study including all the cases which attended the department of Ophthalmology of Shree Birendra Hospital in April 2010 to April 2011.

Results: A total of 17988 patients were seen during the study period with mean age $39.95 \pm 18.94$ years, male to female ratio of 51.02: $48.92 \%$ in the department of Ophthalmology. Among them 4779 were regular serving army personnel and 13209 were ex-army and army families. The largest number of cases were seen in lens related disease (25.19\%), followed by conjunctival and scleral disease (24.29\%).

Conclusions: The pattern of eye disease varies in different age groups. In younger age group conjunctival, scleral disease and refractive error were commonly seen whereas in elder age group lens disorder was frequently seen. The number of blind patients was more in females than in male patients.
\end{abstract}

Keywords: cataract; conjunctivitis; blindness.

\section{INTRODUCTION}

Blindness is one of the most tragic yet often avoidable disabilities in the developing world ${ }^{1}$. The pattern of eye diseases vary in different parts of Nepal due to differences in socioeconomic and geographic factors. The army hospital in Kathmandu not only treats army personnel but also their family and ex- servicemen. A study of the profile of ocular diseases is very important; however no such analytical and descriptive study has been performed at Shree Birendra Hospital. This study was performed to analyze the pattern of ocular diseases in patients coming as outpatient ophthalmology department and use these data for future planning.

\section{METHODS}

This was a retrospective study and all the new cases which were diagnosed in the department of Ophthalmology, Shree Birendra Hospital from 14 $4^{\text {th }}$
April 2010 to $13^{\text {th }}$ April 2011 were included. The patients were first seen in the general outpatient department before being referred to the eye clinic on account of ocular symptoms. All patients were seen by consultant ophthalmologists. For each patient the distance and near visual acuity was recorded using the Snellen or illiterate E chart and near chart except when this was not possible e.g. in infants and preschool children. The anterior segment was examined with the slit lamp. Posterior segment examination was done using a direct ophthalmoscope or 90 Diopter lens with the pupils dilated, if found necessary. Vision is classified as follows, Normal Vision: 6/6- 6/18, Visual Impairment: <6/18- 6/60, Severe Visual Impairment: < $6 / 60-3 / 60$ and Blind: $<3 / 60$. Data was tabulated and interpreted in terms of percentage using SPSS version 18.0. The ocular diseases were divided into different 12 groups (Table 1).

\section{Correspondence:}

Col. Dr. Ramesh Raj Bist

Dept of Ophthalmology, Shree Birendra Hospital, Chhauni, Kathmandu

E-mail: bistdr.rameshraj@yahoo.com 
Table 1: Division of ocular diseases.

\begin{tabular}{|l|l|}
\hline Group & Description \\
\hline Group I & Normal i.e. no ocular problem. \\
\hline $\begin{array}{l}\text { Group II (Lid \& } \\
\text { Adenexa) }\end{array}$ & $\begin{array}{l}\text { Chalazion, Stye, Blepharitis, Acute/ Chronic Dacryocystitis, Dacryoadenitis, } \\
\text { Entropion, Ectropion, Congenital Dacryocystitis, post/ failed DCR Surgery, } \\
\text { Ethmoidocele, Ptosis, Pre-septal Cellulitis, Cellulitis, Caranculitis, Trichiasis, } \\
\text { Lid Edema, Epiphora, Concretion, Meibominitis, Wart, Canthal Cyst etc. }\end{array}$ \\
\hline $\begin{array}{l}\text { Group III (Conjunctiva } \\
\text { \& Sclera) }\end{array}$ & $\begin{array}{l}\text { Conjunctivitis, Trachoma, Pinguecula, Pterygium, Episcleritis, Scleritis, Sub } \\
\text { Conjunctival Haemorrhage, Dry Eye, Conjunctival Cyst/ Naevus/ Melanoma } \\
\text { etc. }\end{array}$ \\
\hline Group IV (Cornea) & $\begin{array}{l}\text { Keratitis, Laceration, Dystrophies, Degeneration, Opacity, Ulcer, Foreign body, } \\
\text { Microcornea, Bullous Keratopathy, Penetrating Keratoplasty Etc. }\end{array}$ \\
\hline Group V (Lens) & $\begin{array}{l}\text { Cataract, Pseudophakia, Aphakia, Subluxated Lens, Posterior Capsular } \\
\text { Opacification etc. }\end{array}$ \\
\hline Group VI (Uveal Tract) & Uveitis, Endophthalmitis, Panophthalmitis etc. \\
\hline Group VII & Refractive errors, Presbyopia, Asthenopia, Amblyopia, Headache etc. \\
\hline Group VIII & Nekebadi (Annual Medical Check Up) of army personnel. \\
\hline $\begin{array}{l}\text { Group IX (Posterior } \\
\text { Segment) }\end{array}$ & $\begin{array}{l}\text { Retinopathies, Macular diseases, Optic nerve lesions, Vitreous lesions, Retinal/ } \\
\text { choroidal detachment etc. }\end{array}$ \\
\hline Group X (Glaucoma) & Primary and secondary glaucoma, glaucoma suspect etc. \\
\hline Group XI (Tumours) & $\begin{array}{l}\text { consists of any neoplasm effecting eye include Ca Maxilla, melanoma, cerebro- } \\
\text { pontine angle tumor, glioma, angioma etc. }\end{array}$ \\
\hline Group XII (Others) & $\begin{array}{l}\text { Systemic diseases affecting eye (HTN, DM, Thyroid Disease, Henson's } \\
\text { Disease, Chicken Pox, Meningitis, Myasthenia Gravis, Seizure Disorder, } \\
\text { Gilbert syndrome, Aplastic Anemia, Hepatitis, Vertigo, Xanthelesma, Amarousis } \\
\text { Fugax, Urethritis,), Proptosis, Artificial Eye, Anophthalmos, Contracted Socket, } \\
\text { Atrophic/ Phthisis Bulbi, Diplopia, Post Lightening, Retrobulbar Neuritis, } \\
\text { Trauma, Squint, Computer Vision Syndrome, Cranial Nerve Palsies (3r, }, 4^{\text {th }}, 5^{\text {th }}, \\
6^{\text {th }}, 7^{\text {th }} \text { ) etc. }\end{array}$ \\
\hline
\end{tabular}

\section{RESULTS}

The total of 17988 patients were recorded during the study period. Among them 4779 were serving soldiers and 13209 were either ex-army or army families. Some patients had one problem in one eye and some had more than one problem in one or both eyes, so among 17988 patients, there were 39356 different problems.
The youngest patient was of 2 months and eldest was of 96 years with mean age 39.95 18.94 years. Among 17988 cases $53.6 \%$ were male and $46.4 \%$ were female with male female ratio of 1.17:1. However, male were predominant among the serving soldiers with the male female ratio of 14:1 (Table 2). Among the number of serving army personnel, male (3724) was more than female (255). 
Table 2: Diagnosis and Age Group:

\begin{tabular}{|l|c|c|c|c|c|}
\multirow{2}{*}{ NAD } & \multicolumn{4}{|c|}{ Age Category } & \multirow{2}{*}{ Total (\%) } \\
\cline { 2 - 5 } & $\mathbf{0 - 1 4 ( \% )}$ & $\mathbf{1 5 - 4 0 ( \% )}$ & $\mathbf{4 1 - 6 0 ( \% )}$ & $>\mathbf{6 0 ( \% )}$ & \\
\hline Lid \& Adenexa & $81(2.77)$ & $371(2.47)$ & $94(0.91)$ & $36(0.32)$ & $582(1.47)$ \\
\hline Conjunctiva \& Sclera & $274(9.37)$ & $971(6.47)$ & $404(3.92)$ & $279(2.50)$ & $1928(4.89)$ \\
\hline Cornea & $1182(40.45)$ & $5399(35.99)$ & $1898(18.46)$ & $1083(9.70)$ & $9562(24.29)$ \\
\hline Lens & $19(4.41)$ & $1065(7.10)$ & $429(4.17)$ & $297(2.66)$ & $1920(4.87)$ \\
\hline Uveal Tract & $11(0.37)$ & $99(0.66)$ & $48(0.46)$ & $26(0.23)$ & $184(0.46)$ \\
\hline Refractive Error & $1068(36.55)$ & $3122(20.81)$ & $2345(22.81)$ & $758(6.79)$ & $7293(18.53)$ \\
\hline Nekebadi & $0(0.0)$ & $2333(15.55)$ & $846(8.22)$ & $0(0.0)$ & $3179(8.08)$ \\
\hline Posterior Segment & $19(0.65)$ & $287(1.91)$ & $312(3.05)$ & $465(4.08)$ & $1083(2.75)$ \\
\hline Glaucoma & $19(0.65)$ & $543(3.62)$ & $625(6.07)$ & $446(3.99)$ & $1633(1.14)$ \\
\hline Tumors & $10(0.34)$ & $21(0.14)$ & $14(0.13)$ & $0(0.0)$ & $45(0.11)$ \\
\hline Others & $110(3.76)$ & $567(3.78)$ & $702(6.82)$ & $653(5.85)$ & $2032(5.16)$ \\
\hline Total (\%) & $\mathbf{2 9 2 2 ( 7 . 4 2 )}$ & $\mathbf{1 4 9 9 8 ( 3 8 . 1 0 )}$ & $\mathbf{1 0 2 8 0 ( 2 6 . 1 2 )}$ & $\mathbf{1 1 1 5 6 ( 2 8 . 3 4 )}$ & $\mathbf{3 9 3 5 6}(\mathbf{1 0 0 . 0})$ \\
\hline
\end{tabular}

Among 39356 cases, total blind cases were 3973, the maximum number of blind cases (1866) was due to lens and its disorders which accounted $18.82 \%$ of lens problem and $4.74 \%$ among the total cases that attended in OPD and $46.96 \%$ of whole blind cases. Similarly $22.6 \%$ (434) of corneal disorder cases were blind i.e. $10.9 \%$ of whole blind cases and $1.1 \%$ cases were blind due to corneal disorder. Blindness due to conjunctival and scleral diseases and posterior segment accounted for $1.47 \& 0.69 \%$ (579 \& 270) respectively. In 512 cases, vision could not be taken as either very small patient (baby) or anophthalmic cases or uncooperative patients.

In all age groups, except $>60$ years and $41-60$ years, the most common ocular disease was conjunctival \& scleral disorders 9562 (24.29\%) followed by refractive error $7293(18.53 \%)$. In the group $>60$ years, the maximum number of patients were of lens disorder $7113(66 \%)$ and $2^{\text {nd }}$ most common disease was conjunctiva $\&$ scleral problem $1083(11.33 \%)$ followed by refractive error $758(10.4 \%)$, others $653(5.8 \%)$ and posterior segment problem accounted 465 (4.16\%). In age group 41-60 yrs, the most common disease was lens disorder 2563 (24.93\%) followed by refractive error 2345 (22.81\%) (Table 2).

In age group 15-40 yrs \& 0-14 yrs also conjunctival \& scleral disorder was the most common problem 1182 \& 5399 (40.45 \& 35.99\%) respectively. In these groups second most common problem was refractive error $1068 \& 3122$ (36.55 \& 20.81\%).
In the age group $0-14 \mathrm{yrs}, 66.05 \%$ had normal vision, $12.11 \%$ had visual impairment, $4.520 \%$ had severe visual impairment and 5.62\% were blind. In $15-40 \mathrm{yr}$ age group $5.58 \%$ were blind. Similarly $17.2 \& 11.76 \%$ patients were blind in 41-60 yrs \& $>60$ yrs respectively.

The percentage of blind patient was the highest in the age group of 41-60 yrs i.e. $4.22 \%$ of whole attending OPD patients. Among the age group $>60$ yrs about $3.1 \%$ patients were blind and that of age group $15-40$ yrs was $2.31 \%$ and in youngest group was $0.44 \%$ of whole attending OPD patients.

$54.85 \%$ patients were male and $45.14 \%$ were female patients. Among male patients $7.99 \%$ were blind, $2.90 \%$ had SVI, 9.65\% had VI and $77.09 \%$ had normal vision. Similarly among females, $66.05 \%$ had normal vision, $15.45 \%$ had VI, $3.6 \%$ had SVI and $12.27 \%$ were blind. Thus this OPD data showed there was larger number of blind patients in female than male.

Out of 3179 cases of Nekebadi (Serving soldiers' ophthalmic status) of 1420 personnel, 2006 (63.1\%) cases were normal, other disease or defects seen in the abnormal eyes were treated as cases as shown below in Table 4 shows the number of regular army personnel who attended OPD for Nekebadi (routine medical check up). Among rest 1173 (36.9\%), 15.62 (497) had conjunctival \& scleral problem, 10.46 (332) had refractive errors, 3.8 (121) had lid \& adenexal problem, 2.24 (71) had corneal problem, 0.38 (12) had lens, 0.2 (6) had uveal tract, 1.07 (35) had posterior segment, 1.04 (33) had glaucoma and 2.09 (66) had others problem. 


\section{DISCUSSION}

Three out of one hundred Nepalese are either blind, severely visually impaired or have low vision. There are over 1 million people with marked vision loss in Nepal: 120,000 blind (unable to count finger at 3 meters); 275,000 with severe visual impairment (unable to count finger at 6 meters) and 750,000 with low vision. Every day 125 Nepalese become blind. There are 30,240 blind children and over 90,000 low vision children. Every day 7 children become blind ${ }^{2}$.

285 million people are visually impaired worldwide: 39 million are blind and 246 million have low vision. About $90 \%$ of the world visually impaired live in developing countries. The number of people visually impaired from infectious diseases has greatly reduced in the last 20 years. $80 \%$ of all visual impairment can be avoided or cured ${ }^{3}$.

Avoidable blindness is defined as blindness which could be either treated or prevented by known, cost effective means. Among the main causes of avoidable blindness are cataract, refractive errors (myopia, hyperopia and astigmatism), glaucoma, diabetic retinopathy and agerelated macular degeneration ${ }^{4}$.

Over the last twenty years, the causes of blindness have changed in proportion and actual number. Cataract has remained the major cause of blindness globally. It is particularly important in Asia. The numbers of people blinded by trachoma, onchocerciasis, and vitamin A deficiency have tended to decrease over the last twenty years ${ }^{5,6}$.

In our study, the major cause of blindness was due to lens and its disorder which accounted $46.96 \%$ of whole blind cases. Second major cause of blindness was due to conjunctiva and scleral disorder $(14.57 \%)$, then corneal cause $(10.92 \%)$ followed by lid and adexenal disorder (8.58\%), posterior segment disorder $(6.79 \%)$, refractive error $(4.6 \%)$ and others $(3.92 \%)$ were the cause of blindness in our study. In worldwide the major cause of blindness is cataract ${ }^{5-12}$.

Besides cataract the cause of blindness vary in different parts of world. The two most common causes of blindness in Asian studies are cataract and under corrected refractive errors. This contrasts with Western populations, in which the leading cause of blindness (accounting for more than $50 \%$ of cases) is age related macular degeneration (AMD) in white people, and cataract and glaucoma in black people However, in Singapore and Mongolia, glaucoma was the principal cause of both unilateral and bilateral blindness while in the Shihpai Eye Study in Taiwan, retinal diseases as a group, including AMD and myopic degeneration were the leading cause ${ }^{5,7,10}$.

\section{OCULAR DISEASE AND AGE GROUP}

In our study, the most frequent ocular disease was conjunctival and scleral disorder in all age groups except the eldest age group, followed by refractive error. However, an increasing number of people are at risk of visual impairment as populations grow and people live longer. Developing countries are already aging much faster than those in the developed world. In 2000 more than 248 million (59\%), of the roughly 418 million persons aged 65 and over, lived in developing countries. By the year 2020 this is projected to rise to $67 \%$. The UN estimates that by 2020 there will be a global elderly population of 698 million ${ }^{3}$.

In the youngest age group (0-14 yrs), the most common problem is of conjunctival and scleral disease followed by refractive error, corneal disorders which were similar with other studies ${ }^{12,} 13-16$.

It is important that screening of children for refractive errors are carried out at community level and integrated into school health programmes. The existing need should be assessed to determine appropriate education and awareness campaigns that would aim to ensure that corrections are used and cultural barriers to compliance are addressed and removed ${ }^{17}$.

In the elder age group like group of 41-60 years, lens disorder was seen most commonly (24.93\%) followed by refractive error $(22.8 \%)$, conjunctival and scleral disease $(18.46 \%)$, others $(6.82 \%)$. The proportion of subjects with normal vision $(\geq 6 / 12)$ was shown to decrease significantly with increasing age. The age specific blindness prevalence was found to be greater with increased age ${ }^{8}$.

In our study also as the increased age, the pattern of disease also varies. Lens disorder was seen as the most common problem in eldest age group (66\%) followed by conjunctival and scleral problem, refractive error and then posterior segment problem, glaucoma. 
Table 3: Age, Sex and Visual Acuity of patients:

\begin{tabular}{|c|c|c|c|c|c|c|c|c|c|c|c|c|}
\hline \multirow[b]{2}{*}{ Age } & \multicolumn{6}{|c|}{ RE VA Category } & \multicolumn{6}{|c|}{ LE VA Category } \\
\hline & $\begin{array}{c}\text { Cannot } \\
\text { be taken } \\
(\%)\end{array}$ & $\begin{array}{l}6 / 6- \\
6 / 18 \\
(\%)\end{array}$ & $\begin{array}{c}<6 / 18- \\
6 / 60 \\
(\%)\end{array}$ & $\begin{array}{c}<6 / 60- \\
3 / 60 \\
(\%)\end{array}$ & $\begin{array}{c}<3 / 60 \\
(\%)\end{array}$ & $\begin{array}{l}\text { Total } \\
(\%)\end{array}$ & $\begin{array}{c}\text { Cannot } \\
\text { be } \\
\text { taken } \\
(\%)\end{array}$ & $\begin{array}{l}6 / 6- \\
6 / 18 \\
(\%)\end{array}$ & $\begin{array}{c}<6 / 18- \\
6 / 60 \\
(\%)\end{array}$ & $\begin{array}{c}<6 / 60- \\
3 / 60 \\
(\%)\end{array}$ & $\begin{array}{c}<3 / 60 \\
(\%)\end{array}$ & $\begin{array}{l}\text { Total } \\
(\%)\end{array}$ \\
\hline $0-14$ & $\begin{array}{c}191 \\
(11.7)\end{array}$ & $\begin{array}{c}1080 \\
(66.05)\end{array}$ & $\begin{array}{c}198 \\
(12.11)\end{array}$ & $\begin{array}{c}74 \\
(4.52)\end{array}$ & $\begin{array}{c}92 \\
(5.62)\end{array}$ & $\begin{array}{l}1635 \\
(8.3)\end{array}$ & $\begin{array}{c}192 \\
(11.7)\end{array}$ & $\begin{array}{c}1102 \\
(67.56)\end{array}$ & $\begin{array}{c}172 \\
(10.54)\end{array}$ & $\begin{array}{c}80 \\
(4.90)\end{array}$ & $\begin{array}{c}85 \\
(5.21)\end{array}$ & $\begin{array}{l}1631 \\
(8.3)\end{array}$ \\
\hline $15-40$ & $\begin{array}{c}71 \\
(0.9)\end{array}$ & $\begin{array}{c}6684 \\
(84.24)\end{array}$ & $\begin{array}{c}638 \\
(8.04)\end{array}$ & $\begin{array}{c}98 \\
(1.23)\end{array}$ & $\begin{array}{c}443 \\
(5.58)\end{array}$ & $\begin{array}{c}7934 \\
(40.27)\end{array}$ & $\begin{array}{c}71 \\
(0.9)\end{array}$ & $\begin{array}{c}6770 \\
(85.53)\end{array}$ & $\begin{array}{c}473 \\
(5.97)\end{array}$ & $\begin{array}{c}133 \\
(1.68)\end{array}$ & $\begin{array}{c}468 \\
(5.91)\end{array}$ & $\begin{array}{c}7915 \\
(40.27)\end{array}$ \\
\hline $41-60$ & $\begin{array}{c}87 \\
(1.78)\end{array}$ & $\begin{array}{c}3212 \\
(65.79)\end{array}$ & $\begin{array}{c}606 \\
(12.41)\end{array}$ & $\begin{array}{c}137 \\
(2.80)\end{array}$ & $\begin{array}{c}840 \\
(17.2)\end{array}$ & $\begin{array}{c}4882 \\
(24.78)\end{array}$ & $\begin{array}{c}81 \\
(1.64)\end{array}$ & $\begin{array}{c}3243 \\
(66.59)\end{array}$ & $\begin{array}{c}584 \\
(11.99)\end{array}$ & $\begin{array}{c}140 \\
(2.87)\end{array}$ & $\begin{array}{c}822 \\
(16.87)\end{array}$ & $\begin{array}{c}4870 \\
(24.78)\end{array}$ \\
\hline$>60$ & $\begin{array}{l}116 \\
(2.2)\end{array}$ & $\begin{array}{c}3164 \\
(60.25)\end{array}$ & $\begin{array}{c}1246 \\
(23.72)\end{array}$ & $\begin{array}{c}107 \\
(2.03)\end{array}$ & $\begin{array}{c}618 \\
(11.76)\end{array}$ & $\begin{array}{c}5251 \\
(26.65)\end{array}$ & $\begin{array}{l}147 \\
(2.8)\end{array}$ & $\begin{array}{c}2881 \\
(55.0)\end{array}$ & $\begin{array}{c}1396 \\
(26.65)\end{array}$ & $\begin{array}{c}209 \\
(3.99)\end{array}$ & $\begin{array}{c}605 \\
(11.55)\end{array}$ & $\begin{array}{c}5238 \\
(26.65)\end{array}$ \\
\hline Total & $\begin{array}{c}465 \\
(2.37)\end{array}$ & $\begin{array}{c}14140 \\
(71.70)\end{array}$ & $\begin{array}{c}2688 \\
(13.64)\end{array}$ & $\begin{array}{c}416 \\
(2.11)\end{array}$ & $\begin{array}{c}1993 \\
(10.1)\end{array}$ & $\begin{array}{l}19702 \\
(100.0)\end{array}$ & $\begin{array}{l}491 \\
(2.5)\end{array}$ & $\begin{array}{c}13996 \\
(71.21)\end{array}$ & $\begin{array}{c}2625 \\
(13.35)\end{array}$ & $\begin{array}{c}562 \\
(2.85)\end{array}$ & $\begin{array}{c}1980 \\
(10.07)\end{array}$ & $\begin{array}{r}19654 \\
(100.0)\end{array}$ \\
\hline \multicolumn{13}{|l|}{ Sex } \\
\hline Male & $\begin{array}{c}238 \\
(2.38)\end{array}$ & $\begin{array}{c}7742 \\
(77.05)\end{array}$ & $\begin{array}{c}936 \\
(9.31)\end{array}$ & $\begin{array}{c}299 \\
(2.97)\end{array}$ & $\begin{array}{c}830 \\
(8.26)\end{array}$ & $\begin{array}{c}10045 \\
(50.98)\end{array}$ & $\begin{array}{c}230 \\
(2.30)\end{array}$ & $\begin{array}{c}7740 \\
(77.13)\end{array}$ & $\begin{array}{c}1004 \\
(10.0)\end{array}$ & $\begin{array}{c}284 \\
(2.83)\end{array}$ & $\begin{array}{c}776 \\
(7.73)\end{array}$ & $\begin{array}{l}10034 \\
(51.06)\end{array}$ \\
\hline Female & $\begin{array}{c}227 \\
(2.35)\end{array}$ & $\begin{array}{c}6394 \\
(66.22)\end{array}$ & $\begin{array}{c}1510 \\
(15.63)\end{array}$ & $\begin{array}{c}361 \\
(3.73)\end{array}$ & $\begin{array}{c}1163 \\
(12.04)\end{array}$ & $\begin{array}{c}9655 \\
(49.02)\end{array}$ & $\begin{array}{c}262 \\
(2.72)\end{array}$ & $\begin{array}{c}6338 \\
(65.88)\end{array}$ & $\begin{array}{c}1476 \\
(5.34)\end{array}$ & $\begin{array}{c}340 \\
(3.53)\end{array}$ & $\begin{array}{c}1204 \\
(12.51)\end{array}$ & $\begin{array}{c}9620 \\
(48.94)\end{array}$ \\
\hline Total & $\begin{array}{c}465 \\
(2.37)\end{array}$ & $\begin{array}{c}14136 \\
(71.74)\end{array}$ & $\begin{array}{c}2446 \\
(12.41)\end{array}$ & $\begin{array}{c}660 \\
(3.34)\end{array}$ & $\begin{array}{c}1993 \\
(10.11)\end{array}$ & $\begin{array}{c}19700 \\
(100.0)\end{array}$ & $\begin{array}{c}492 \\
(2.5)\end{array}$ & $\begin{array}{c}14078 \\
(71.62)\end{array}$ & $\begin{array}{c}2480 \\
(12.61)\end{array}$ & $\begin{array}{c}624 \\
(3.17)\end{array}$ & $\begin{array}{c}1980 \\
(10.07)\end{array}$ & $\begin{array}{r}19654 \\
(100.0)\end{array}$ \\
\hline
\end{tabular}

\section{OCULAR DISEASE AND SEX}

There was a marked difference in presenting visual acuity between women and men. In our study the number of female blind patients was more than that of male patients. There was a higher prevalence of blindness in women $(1.72 \%)$ than men $(1.06 \%)$ in the study conducted in Bangladeshi adults. Similar findings are seen in other studies ${ }^{8,9,18-23}$. Our experience on the pattern of eye diseases among the regular serving forces compares favorably with a study conducted in an Air Force Hospital in Nigeria ${ }^{16}$ where conjunctival and sclera disorders, refractive errors and glaucoma were the most common ocular disorders among regular army personnel. Similarly, Nowak et al ${ }^{24}$ observed that the commonest ocular disorder in candidates and members of the Polish military service was refractive error. However, the other major ocular disorders seen in the Polish study were not observed among the armed forces personnel in this series. These are color vision disturbances and strabismus. In Washington ${ }^{25}$, the most common ocular diseases and non-battle injuries seen in military personnel were uveitis, retinal detachment, infectious keratitis and choroidal neovascularization. 
Table 4: Visual Acuity and Diagnosis:

\begin{tabular}{|c|c|c|c|c|c|c|c|c|c|c|c|c|c|c|c|c|c|c|}
\hline \multirow{2}{*}{ 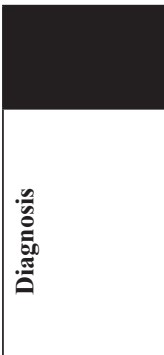 } & \multicolumn{3}{|c|}{$\begin{array}{c}\text { Vision cannot be } \\
\text { taken }\end{array}$} & \multicolumn{3}{|c|}{$\begin{array}{l}\text { Normal } \\
(6 / 6-6 / 18)\end{array}$} & \multicolumn{3}{|c|}{$\begin{array}{c}\text { Visual Impairment } \\
(<6 / 18-6 / 60)\end{array}$} & \multicolumn{3}{|c|}{$\begin{array}{l}\text { Severe Visual } \\
\text { Impairment } \\
(<6 / 60-3 / 60)\end{array}$} & \multicolumn{3}{|c|}{$\begin{array}{l}\text { Blind } \\
(<3 / 60)\end{array}$} & \multicolumn{3}{|c|}{ Total } \\
\hline & 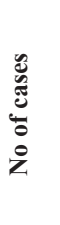 & 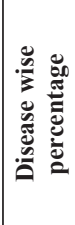 & 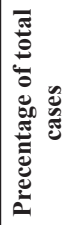 & $\begin{array}{l}\tilde{E} \\
\tilde{E} \\
\tilde{E} \\
\ddot{0} \\
\dot{z}\end{array}$ & 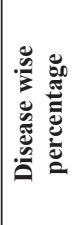 & 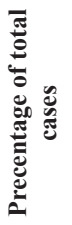 & 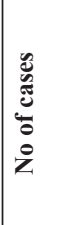 & 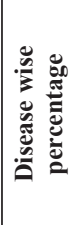 & 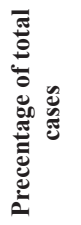 & 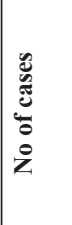 & 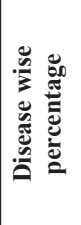 & 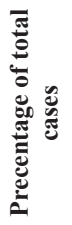 & 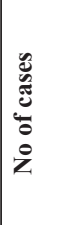 & 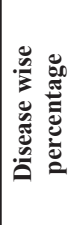 & 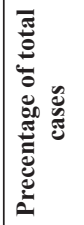 & 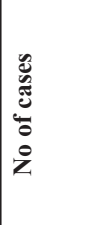 & 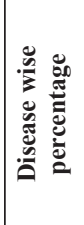 & 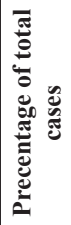 \\
\hline NAD & 36 & 6.19 & 0.09 & 546 & 93.8 & 1.39 & & & & & & & & & & 582 & 100.0 & 1.47 \\
\hline $\begin{array}{c}\text { Lid \& } \\
\text { Adenexa }\end{array}$ & 69 & 3.5 & 0.18 & 1376 & 71.3 & 3.5 & 122 & 6.3 & 0.31 & 20 & 1.0 & 0.05 & 341 & 17.69 & 0.87 & 1928 & 100.0 & 4.89 \\
\hline $\begin{array}{l}\text { Conjunctiva } \\
\text { \& Sclera }\end{array}$ & 263 & 2.75 & 0.67 & 7971 & 83.36 & 20.25 & 675 & 7.06 & 1.72 & 74 & 0.77 & 0.19 & 579 & 6.06 & 1.47 & 9562 & 100.0 & 24.29 \\
\hline Cornea & 5 & 0.26 & 0.01 & 1250 & 65.10 & 3.18 & 185 & 9.64 & 0.47 & 46 & 2.4 & 0.12 & 434 & 22.6 & 1.10 & 1920 & 100.0 & 4.87 \\
\hline Lens & 6 & 0.06 & 0.02 & 2574 & 25.96 & 6.54 & 4374 & 44.12 & 11.11 & 1094 & 11.03 & 2.78 & 1866 & 18.82 & 4.74 & 9914 & 100.0 & 25.19 \\
\hline Uveal Tract & 1 & 0.54 & 0.0 & 108 & 58.70 & 0.27 & 34 & 18.48 & 0.09 & 6 & 3.26 & 0.02 & 35 & 19.02 & 0.09 & 184 & 100.0 & 0.46 \\
\hline $\begin{array}{l}\text { Refractive } \\
\text { Error }\end{array}$ & 20 & 0.27 & 0.05 & 6177 & 84.70 & 15.7 & 826 & 11.33 & 2.1 & 87 & 1.19 & 0.22 & 183 & 2.51 & 0.46 & 7293 & 100.0 & 18.53 \\
\hline Nekebadi & 0 & 0.0 & 0.0 & 3133 & 98.55 & 0.34 & 43 & 1.35 & 0.11 & 3 & 0.09 & 0.01 & 0 & 0.0 & 0.0 & 3179 & 100.0 & 8.07 \\
\hline $\begin{array}{l}\text { Posterior } \\
\text { Segment }\end{array}$ & 0 & 0.0 & 0.0 & 401 & 37.03 & 1.02 & 295 & 27.24 & 0.75 & 117 & 10.80 & 0.30 & 270 & 24.93 & 0.69 & 1083 & 100.0 & 2.75 \\
\hline Glaucoma & 6 & 0.37 & 0.02 & 1393 & 85.30 & 3.54 & 90 & 5.51 & 0.23 & 45 & 2.76 & 0.11 & 99 & 6.06 & 0.25 & 1633 & 100.0 & 4.14 \\
\hline Tumors & 0 & 0.0 & 0.0 & 34 & 75.56 & 0.09 & 1 & 2.22 & 0.0 & 0 & 0 & 0 & 10 & 22.22 & 0.03 & 45 & 100.0 & 0.11 \\
\hline Others & 106 & 5.21 & 0.27 & 1273 & 62.62 & 3.23 & 422 & 20.76 & 1.07 & 76 & 3.74 & 0.19 & 156 & 7.67 & 0.4 & 2032 & 100.0 & 5.16 \\
\hline Total & 512 & & 1.3 & 26236 & & 66.66 & 7067 & & 17.96 & 1568 & & 3.98 & 3973 & & 10.10 & 39356 & & 100.0 \\
\hline
\end{tabular}

Out of 3179 cases of nekebadi of 1420 personnel, 2006 cases were normal, other disease or defects seen in the abnormal eyes were treated as cases as shown below in table 5 .

Table 5: Annual Checkup ophthalmic status of serving soldier

\begin{tabular}{|l|l|l|}
\hline NAD & Frequency & Percentage \% \\
\hline Lid \& Adenexa & 2006 & 63.1 \\
\hline $\begin{array}{l}\text { Conjunctiva \& } \\
\text { Sclera }\end{array}$ & 497 & 3.8 \\
\hline Cornea & 71 & 15.62 \\
\hline Lens & 12 & 2.24 \\
\hline Uveal Tract & 6 & 0.38 \\
\hline $\begin{array}{l}\text { Refractive } \\
\text { Error }\end{array}$ & 332 & 0.2 \\
\hline $\begin{array}{l}\text { Posterior } \\
\text { Segment }\end{array}$ & 35 & 10.46 \\
\hline Glaucoma & 33 & 1.07 \\
\hline Tumors & 0 & 1.04 \\
\hline
\end{tabular}

\begin{tabular}{|l|l|l|}
\hline Others & 66 & 2.09 \\
\hline Total (\%) & $\mathbf{3 1 7 9}$ & $\mathbf{1 0 0}$ \\
\hline
\end{tabular}

\section{CONCLUSIONS}

The leading cause of eye diseases in this study was lens related disease, conjunctival and scleral disease and refractive error. The pattern of diseases observed among army personnel was similar to the civilian patients.

\section{REFERENCES}

1. Resnikoff $\mathrm{S}$ et al. Global data on visual impairment in the year 2002: Bull World Health Organ 2004; 82: 844-851. PMid: 15640920

2. Blindness and Visual impairment in Nepal: Facts and Figures. Mid term review of Vision 2020: The Right to Sight Nepal, 2011. Apex Body for Eye Health, Ministry of Health and Population, Government of Nepal. (as of December 2010)

3. Resnikoff S, Pascolini D, Etya'ale D et al. Global data on visual impairment in the year 2002. Bulletin of the World Health Organization 2004; 
82: 844-851. PMid:15640920

4. Solange R. Salomão; Márcia R. K. H. Mitsuhiro; Rubens Belfort Jr. Visual impairment and blindness: an overview of prevalence and causes in Brazil. Annals of the Brazilian Academy of Sciences 2009; 81(3): 539-49. http://dx.doi. org/10.1590/S0001-37652009000300017

5. Allen Foster, Clare Gilbert et al. Changing patterns in global blindness: 1988-2008. Community Eye Health J 2008; 21(67): 37-39.

6. Whitcher JP, Upadhyay MP et al. Corneal blindness: a global perspective. Bull World Health Organ 2001; vol.79 no.3: 214-21. PMid:11285665

7. Thylefors B, Négrel AD, Pararajasegaram R, Dadzie KY. Global data on blindness. Bull World Health Organ. 1995; 73(1):115-21. PMid:7704921

8. Sapkota YD, Pokharel GP et al. Prevalence of blindness and cataract surgery in Gandaki Zone, Nepal: Br J Ophthalmol 2006; 90: 411416. http://dx.doi.org/10.1136/bjo.2005.082503 PMid:16547315

9. Dineen BP, Bourne RRA et al. Prevalence and causes of blindness and visual impairment in Bangladeshi adults: results of the National Blindness and Low Vision Survey of Bangladesh: Br J Ophthalmol. 2003 July; 87(7): 820-828. http:// dx.doi.org/10.1136/bjo.87.7.820 PMid:12812875

10. Dr Ivo Kocur. Global pattern of blindness changes with success in tackling infectious disease and as population ages: Bulletin of the World Health Organization. DECEMBER 2004.

11. Wong T Y, Loon S-C et al. The epidemiology of age related eye diseases in Asia: Br J Ophthalmol 2006; 90: 506-511. http://dx.doi.org/10.1136/ bjo.2005.083733 PMid:16547337

12. Ogwurike S, Pam V Pattern of Eye Diseases in Kaduna State - A rural community outreach experience: Nigerian Journal of Ophthalmology. $(2004 ; 12(1)$

13. Ajaiyeoba AI, Isawumi MA. et al. Prevalence and Causes of Eye Diseases amongst Students in South-Western Nigeria. Annals of African Medicine. 2006;5(4):197-203.

14. Ajaiyeoba AI, Isawumi MA. et al. Pattern of eye diseases and visual impairment among students in southwestern Nigeria. Int Ophthalmol.2007; 27:287-92. http://dx.doi.org/10.1007/s10792007-9056-7 PMid:17585376

15. Kehinde AV, Ogwurike SC et al. School eye health screening in Kaduna -Northern Nigeria. Nigerian journal of surgical research . 2005;7(1-2):1914.

16. Olukorede O. Adenuga, Oluyinka J. Samuel. Pattern of Eye Diseases in an Air Force Hospital in Nigeria. Pak J Ophthalmol. 2012;28(3):1448.

17. Pascolini D, Mariotti SPM. Global estimates of visual impairment: 2010. Br J Ophthalmol. 2012; 96: 614-618. http://dx.doi.org/10.1136/ bjophthalmol-2011-300539 PMid:22133988

18. Brilliant GE, Pokharel RP et al. The epidemiology of blindness in Nepal: report of the 1981 Nepal Blindness Survey. Chelsea, Michigan: The Seva Foundation, 1988. J Ophthalmol. 2003;87(7):820828.

19. Pokharel GP, Regmi G et al. Prevalence of blindness and cataract surgery in Nepal. Br J Ophthalmol. 1998; 82: 600-5.http://dx.doi. org/10.1136/bjo.82.6.600

20. Dandona L, Dandona $\mathrm{R}$ et al. Is current eyecare policy focus almost exclusively on cataract adequate to deal with blindness in India? Lancet 1998; 351:1312-16. http://dx.doi.org/10.1016/ S0140-6736(97)09509-3

21. Murthy GVS, Gupta S et al. A population-based eye survey of older adults in a rural district of Rajasthan. I. Central vision impairment, blindness, and cataract surgery. Ophthalmology 2001; 108: 679-85. http://dx.doi.org/10.1016/ S0161-6420(00)00579-0

22. Anthony V. Perruccio, Elizabeth M. Badley, Graham E. Trope. A Canadian populationbased study of vision problems: assessing the significance of socioeconomic status. CAN J OPHTHALMOL_VOL. 45, NO. 5, 2010: 47783.

23. AO Oduntan. Prevalence and causes of low vision and blindness worldwide. S Afr Optom 200564 (2) $44-54$.

24. Nowak MS, Goś R, Smigielski J. Epidemiology of ocular diseases-a review of medical examinations from The Area of Military Medical Commission in Lodz. Klin Oczna. 2009; 111: 425. PMid:19517845

25. Psolka M, Bower KS, Brooks DB, et al. Ocular diseases and non-battle injuries seen at a tertiary care medical center during the global war on terrorism. Mil Med. 2007; 172: 491-7. PMid:17521096 